https://helda.helsinki.fi

\title{
Arthur Annesley, Margaret Cavendish, and Neo-Latin History
}

\author{
Begley, Justin
}

2018-11

Begley, J 2018 , ' Arthur Annesley, Margaret Cavendish, and Neo-Latin History ', Review of

English Studies , vol. 69 , no. 292 , hgy069 , pp. 855-873 . https://doi.org/10.1093/res/hgy069

http://hdl.handle.net/10138/318477

https://doi.org/10.1093/res/hgy069

acceptedVersion

Downloaded from Helda, University of Helsinki institutional repository.

This is an electronic reprint of the original article.

This reprint may differ from the original in pagination and typographic detail.

Please cite the original version. 


\title{
Arthur Annesley, Margaret Cavendish, and Neo-Latin History
}

\author{
Justin Begley
}

\begin{abstract}
This article explores a hitherto unstudied copy of De vita [...] Guilielmi ducis NovoCastrensis (1668) - a Latin translation of The Life of William Cavendish (1667) by Margaret Cavendish (1623?-1673) — that Arthur Annesley (1614-1686), the First Earl of Anglesey, has heavily annotated. While Annesley owned the largest private library in seventeenth-century Britain, his copy of De vita is by far the most densely glossed of his identifiable books, with no fewer than sixty-one Latin and Greek annotations, not to mention numerous corrections and non-verbal markers. By studying Annesley's careful treatment of De vita, this essay makes an intervention into the burgeoning fields of reading and library history along with neo-Latin studies. I propose that Annesley filled the margins of De vita with quotations from Latin poets, scholars, philosophers, and historians - rather than his personal views-in a bid to form a politically impartial outlook on the British Civil Wars that was attuned to broader historical or even mythological trends.
\end{abstract}

\section{INTRODUCTION}

On 18 March 1668, the renowned diarist, Samuel Pepys (1633-1703), recorded that he had stayed 'home reading the ridiculous history of my Lord Newcastle wrote by his wife, which shows her to be a mad, conceited, ridiculous woman, and he an asse to suffer [her] to write what she writes to him and of him.'. Pepys's evaluation of Margaret Cavendish (1623?-1673) and her 1667 The Life of William Cavendishe-an account of the deeds of her husband, William Cavendish (1592-1676), in the British Civil Wars-has fuelled the view that contemporaries either scorned or neglected her books. ${ }^{2}$ Yet, in spite of Pepys's assessment, Cavendish's history went through numerous editions over the years. A faithful Latin translation of her Life probably by the celebrated physician, Walter Charleton (1619-1707), appeared in 1668 as De vita [...] Guilielmi ducis Novo-castrensis; an English redaction was published two years after her death in 1675; and nineteenth-century historians regarded her work

Many thanks to William Poole, Jim Fitzmaurice, Lisa Sarasohn, Colin Burrow, and two anonymous referees for their helpful comments on this article.

1 Samuel Pepys, The Diary of Samuel Pepys: A New and Complete Transcription, ed. Robert Latham and William Matthews, vol. 9 (London, 1974), 123.

2 For how Pepys's account has shaped Cavendish's reception, see Lisa Sarasohn, 'Margaret Cavendish, William Newcastle, and Political Marginalization', English Studies, 92 (2011), 806-17 (808-9) and Paul Salzman, Reading Early Modern Women's Writing (Oxford, 2006), 167-72.

(C) The Author(s) 2018. Published by Oxford University Press 2018; all rights reserved 
as a seminal source on the Civil Wars, spurred by the editions of Mark Lower in 1856, John Russell in 1872, and finally the still authoritative text of C. H. Firth, Regius Professor of Modern History at Oxford, in $1886 .{ }^{3}$ Offering a picture of the early reception of Cavendish's history that fits with these serious appraisals, this article explores a hitherto unstudied copy of De vita in the British Library that has been heavily annotated by the Irish politician, lawyer, and courtly scholar, Arthur Annesley (1614-1686), the First Earl of Anglesey. ${ }^{4}$

It is patent from the front-leaf inscription-'Anglesey. Donum D. ${ }^{\text {ni }}$ Comitis Ogle. nou.18.1676' - that this book was gifted to Annesley by William Cavendish's son, Henry Cavendish (1659-1680), the Earl of Ogle. ${ }^{5}$ Supplementing this evidence, Annesley's 1686 library sale catalogue lists 'Vita Gulielmi Ducis Novo-Casstrensis, per Margaritam Ipsius Uxorem Conscript. 1668' along with the English Life of William and Margaret's 1664 Poems, and Fancies. ${ }^{6}$ His ownership of these books comes as no real shock, since Annesley's private library was the largest of its kind, with over 30,000 volumes. ${ }^{7}$ It is remarkable, however, that his copy of De vita contains no less than sixty-one Latin and occasionally Greek annotations in his hand, not to mention frequent corrections and non-verbal markers. Because Annesley's library was dispersed widely after his death, very few of his libri annotati have been uncovered. ${ }^{8}$ Out of his identifiable books, this copy of De vita is by far the most densely glossed.

Thanks to the concerted efforts of Anthony Grafton, Lisa Jardine, and Ann Blair, historians now have a much firmer grasp of the uses to which Renaissance scholars (chiefly in the sixteenth century) put their books. ${ }^{9}$ Building on these studies, the present article displays how the humanist's active, creative, and goal-orientated reading and note-taking practices continued to guide a distinguished courtier in the latter half of the seventeenth century. But, by contrast to the preoccupations of sixteenthcentury scholars such as Gabriel Harvey, I show that Annesley's annotations were largely indifferent to state affairs. This may seem odd inasmuch as earlier humanists expended the preponderance of their energy reading and interpreting classical Greek

3 Firth evidently consulted various copies of Cavendish's work in preparing his edition; he has notably annotated the Christ Church copy by offering, in the front-leaf, the code to a number of contentious phrases that Cavendish had blacked out: see The Life of the thrice noble, high, and puissant prince William Cavendishe (London, 1667), shelfmark O.104. On the matter of Cavendish's erasures, see James Fitzmaurice, 'Margaret Cavendish on Her Own Writing: Evidence from Revision and Handmade Correction', The Papers of the Bibliographical Society of America, 85 (1991), 297-307.

4 See British Library, De vita [.. .] Guilielmi ducis Novo-castrensis (London, 1668), shelfmark 611.1.16; hereafter De vita. Unless otherwise noted, all references to De vita refer to this copy.

5 On Annesley, see Michael Perceval-Maxwell, 'Arthur Annesley', ODNB.

6 See Arthur Annesley and Thomas Philipps, Bibliotheca Angleseiana, sive, Catalogus variorum librorum (London, 1686), 35, 27, and 28.

7 See Douglas Greene, 'Arthur Annesley, first earl of Anglesey, 1614-1686’ PhD thesis, Chicago, IL, 1972, 98.

8 On the dispersal of Annesley's library, see the sale catalogue that records purchasers and prices in the Lambeth Palace Library, shelfmark Z999. For another instance of a book annotated by Annesley, see his lightly marked copy of John Ponce, D.R. Bellingi vindiciae eversae (Paris, 1653), British Library, shelfmark 860.c.13.

9 Especially see Grafton and Jardin, “Studied for Action”: How Gabriel Harvey Read His Livy', Past \& Present, 129 (1990), 30-78 and Ann Blair, 'The Rise of Note-Taking in Early Modern Europe', Intellectual History Review, 20 (2010), 303-16. 
and Latin literature, while Annesley dedicated his time to a popular history of the Civil Wars. Instead of filling the margins with his own opinions, however, Annesley took a centrifugal approach that converted De vita into a storehouse of relevant passages from the Latin poets, scholars, philosophers, and historians whose books lined his library shelves. In recent years, scholars have stressed the sectarian nature of post-Interregnum culture, and it has even been supposed that the 'venerable humanist practice' of annotation became 'partisan and harshly polemical' after the Restoration. ${ }^{10}$ Yet, using his copy of De vita as a springboard, I argue against the historiographical grain that Annesley (like many of his contemporaries) was not so much concerned with party politics as with meticulously and disinterestedly mapping the recent past onto a much longer history.

After a preliminary identification of the books that Annesley used to annotate De vita, this article examines the reasons for his persistent recourse to Virgil. I make the case that Virgil's poetry aided his endeavour to see beyond historical vagaries and to form, as far as possible, an even-handed picture of the Civil Wars that accorded with recurrent and even universal human behaviour. Situating this discussion in relation to the translation itself - which is written in plain Latin prose and seeks to occlude the translator's identity-I propose that De vita was unavoidably infused with Virgilian language, partly because the Aeneid was heralded as a stylistic model and a touchstone for the teaching of virtue, nobility, and warfare in European schools and universities. The growing body of literature on the dynamic between seventeenth-century vernaculars and neo-Latin writing tends to focus on continental languages, but Annesley's copy of De vita thus proffers a striking insight into how English scholars might consult ancient Latin literature in translating and framing their country's history. ${ }^{11}$ Since De vita spotlights William's personal exploits, Annesley was also driven to illuminate the text with historical biographies that were similarly integral to the education of any young nobleman: Julius Caesar's Commentaries and Cornelius Nepos's Vitae excellentium imperatorum. Pushing against the received notion that life-writing emerged during the seventeenth century, this essay accordingly demonstrates how both Cavendish and Annesley generically placed De vita within a protracted history that harked back to ancient Rome.

Over the course of the article, it becomes clear that Annesley and Cavendish alike were intent on appearing to engage impartially with recent history, yet their visions of what this might entail diverged starkly. The term 'impartial'- which has no obvious Latin correlate-was a sixteenth-century coinage that remained polysemic as it

10 See Steven Zwicker, 'The Constitution of Opinion and the Pacification of Reading', in Kevin Sharpe and Steven Zwicker (eds), Reading, Society, \& Politics in Early-Modern England (Cambridge, 2003), 295-316 (300-1). More generally, see Kevin Sharpe, Reading Revolutions: The Politics of Reading in Early Modern England (New Haven, CT, 2000).

11 See Thomas Deneire (ed.), Dynamics of Neo-Latin and the Vernacular: Language and Poetics, Translation and Transfer (Leiden, 2014); Philip Ford, The Judgment of Palaemon: The Contest Between Neo-Latin and Vernacular Poetry in Renaissance France (Leiden, 2013); Demmy Verbeke, 'Neo-Latin's Interplay with Other Languages', in Stefan Tilg and Sarah Knights (eds), The Oxford Handbook of Neo-Latin (Oxford, 2015), 27-37; and the articles in Latin and the Vernaculars in Early Modern Europe, special issue of Rencessanceforum: Journal of Renaissance Studies, 6 (2012), ed. Trine Hass and Johann Ramminger. 
gained traction over the next century. ${ }^{12}$ As we will see, Cavendish saw impartiality in light of the traditional notion of fides (testimony or credit) and consequently took nobility as a prerequisite for any fair or unbiased account of historical events, whereas Annesley more straightforwardly associated impartiality with a dearth of ideological commitment. In either case, while historians and critics have typically emphasized the most partisan early modern readers of Latin poetry and history, Annesley's De vita affords a powerful example of an eminent politician who handled the classics primarily for intellectual, semantic, and even entertainment purposes.

\section{DETECTING VIRGIL}

Due to Annesley's habit of supplying citations for his extracts, it has been possible to identify each of the volumes that he read alongside De vita. Subsequent sections inspect many of his specific annotations in greater depth, but this list uses Annesley's library catalogue to offer a first impression of the books that he had ready to hand:

1. Thirty-eight quotations are from the Virgil's Aeneid, which Annesley owned in three editions (Rome, 1558; Rome, 1612; and Amsterdam, 1638). ${ }^{13}$

2. Nine quotations are from Virgil's Eclogues. This was included in Virgil's Opera omnia, of which Annesley owned four copies (Paris, 1618; Cologne, 1620; Cologne, 1628; and Paris, 1675). ${ }^{14}$

3. Three quotations are from Cornelius Nepos's Vitae excellentium imperatorum, which Annesley had in two editions (Amsterdam, 1644 and Antwerp, 1675). ${ }^{15}$

4. Two quotations are from Seneca's De consolatione ad Polybium. This was included in Seneca's Opera omnia, of which Annesley owned two copies (Paris, 1619 and Leiden, 1649). ${ }^{16}$

5. One quotation is from Kaspar Schoppe's Scioppii infamia adv. stradam de bello Belgico (Sorø, 1658). ${ }^{17}$

6. One quotation is from Quintus Curtius Rufus's Historiae Alexandri Magni, which Annesley owned in three editions (Leiden, 1633; Amsterdam, 1650; and London, 1680). ${ }^{18}$

7. One quotation is from Livy's Historia Romana, which Annesley had in two editions (Geneva, 1631 and Frankfurt, 1658). ${ }^{19}$

8. One quotation is from Julius Caesar's Commentarii, which Annesley had in four editions (Leiden, 1548; Leiden, 1613; Leiden, 1651; and Amsterdam, 1657). ${ }^{20}$ 
9. One quotation is from Julii pacii epitome juris civilis (Montpellier, 1603). ${ }^{21}$

10. One quotation is from Pierre Gassendi's and Jean-Jacques Bouchard's Viri illustris Nicolai Claudii Fabricii de Peiresc (The Hague, 1655). ${ }^{22}$

11. One quotation is from John Barclay's Argenis, which Annesley owned in two editions (Leiden, 1628 and 1630). ${ }^{23}$

12. One quotation is from Thomas Hobbes's De mirabilibus pecci (absent from his library catalogue, but first published in London, 1627).

Owing to the magnitude of Annesley's library, the editions that he relied on can only be pinpointed in some cases. ${ }^{24}$ No tell-tale marks betray the version of Caesar's Commentaries that he read, for instance, but Annesley cited Nicolas Courtin's Greek notes on Nepos's Vitae excellentium imperatorum, which means that he was putting his recently purchased 1675 edition to good use. ${ }^{25}$ More generally, while Annesley intermittently referenced the Latin publications of modern authors such as Hobbes's De mirabilibus pecci and Barclay's Argenis, he was overwhelmingly concerned with Roman writers. The sheer number of quotations mined from Virgil in particular is the most conspicuous feature of his annotated De vita. Yet this is wholly in keeping with Annesley's library holdings in which copies of Virgil—printed exclusively on the continent with different glosses and commentaries - so predominated that he probably owned more volumes by the great Roman poet than any other British man of the period. ${ }^{26}$

Annesley's transcriptions from the Aeneid and Eclogues are not only plentiful but also unique insofar as they alone are unaccompanied by books, lines, or page numbers. Such an abandonment of citations suggests that his familiarity with Virgilrooted in a juvenile commitment of sententiae to memory-was so thoroughgoing that he could immediately recall the relevant passages or at least locate them without guidance. $^{27}$ This is all the more notable since Annesley did not merely engage in the rote repetition of an uninterested schoolboy, but rather imaginatively rearranged verses from Virgil. On page 73, for example, he wedded Aeneas's yearning for battle with the eventual offensive of his troops: 'Frenzy and anger drive my soul headlong, and I think how glorious it is to die in arms. We charge and stream around them with dense arms' ['Furor iráque mentem / Præcipitant, puterumque mori succurrit

Bibliotheca Angleseiana, 68.

Bibliotheca Angleseiana, 29.

Bibliotheca Angleseiana, 47 and 50.

For the identification of some of Annesley's English books, see Annabel Patterson and Martin Dzelzainis, 'Marvell and the Early of Anglesey: A Chapter in the History of Reading', The Historical Journal, 44 (2001), 703-29 (712-19).

25 See De vita, 98.

On the variety of Latin editions and commentaries on Virgil's work during a slightly earlier period, see David Wilson-Okamura, Virgil in the Renaissance (Cambridge, 2010), 252-66.

On Virgil's use in the classroom, see Margaret Tudeau-Clayton, Jonson, Shakespeare, and Early Modern Virgil (Cambridge, 1998), 72-7; Craig Kallendorf, Virgil and the Myth of Venice: Books and Readers in the Italian Renaissance (Oxford, 1999), 31-81; and especially Andrew Wallace, Virgil's Schoolboys: The Poetics of Pedagogy in Renaissance England (Oxford, 2010). For an account of how two of Annesley's contemporaries, Robert Sanderson and William Oughtred, were able to recite reams of Roman poetry off by heart even into their old age, see Mordechai Feingold, 'The Humanities', in Nicholas Tyacke (ed.), The History of the University of Oxford: Volume IV, Seventeenth Century Oxford (Oxford, 1997), 229. 
in armis. / Irruimus densis, \& circumfundimur armis']. These lines follow on from one another in Annesley's transcription, yet the second and third are not contiguous in Virgil. He rather merged two lines from Book 2 of the Aeneid: 316-7 and 383. As this implies, Annesley was not so much concerned with fidelity to Virgil's original as with reshaping his poetry to capture the essence of episodes in De vita, in this case the fervour of close quarter combat between the Royalists and a Scottish legion.

Along with repeatedly grafting together disparate verses from Virgil to elucidate scenes in De vita, Annesley interpolated significant nouns from De vita into lines from Virgil, sometimes to comic effect. Next to the portrayal on page 127 of William's withdrawal to his country home, Welbeck Abbey, Annesley recorded Meliboeus's question in the Eclogues Book 1, line 26: 'what was the great occasion of you seeing Rome'? Annesley substituted 'Rome' with 'Welbeck', however, implicitly critiquing William's retreat from battle. ${ }^{28}$ This adaption is especially striking in view of Annesley's own politics: after siding with Parliament in the 1640s, he played a crucial role in arranging the Restoration, on condition that his Irish estates would be safeguarded. For his efforts, Annesley was made Lord Privy Seal from 1673 to 1682. Regardless of his political allegiances at the time of annotating De vita, then, he did not see the commander of a Royal legion and a paragon of Royalist military virtue as above mild satire.

Notwithstanding his periodic flippancy, the assiduous nature of Annesley's annotations indicates that reading De vita was by no means simply an amusing pastime. On the contrary, Annesley approached De vita with such dynamism because he intended to compose his own history. This is made evident in a diary entry from 1 June 1676 (only months before receiving De vita) in which he logged his plans to 'write the truth of the history of $y^{\mathrm{e}}$ Latte times in Latin laying moche open wherin others are obscured by flattering him who had good luck but little or no merit'. ${ }^{29}$ Since De vita is a rare Latin account of the Civil Wars-only matched by George Bate's more polemical Elenchus motuum noperorum in Anglia, published in two parts in 1650 and 1661 - it would have been a convenient departure point for his own venture. $^{30}$ By manipulating Virgil's work in the margins of De vita, Annesley attempted to move from historical particulars to the universal patterns of behaviour that, it was widely thought, only poetry could grasp, so as to establish a solid foundation for his own comprehensive and disinterested undertaking. ${ }^{31}$

Virgil of course wrote in an era of political upheaval - as the Roman Empire displaced the Republic - and he associated these occurrences and the monumental feats of Caesar with the bravery of the Trojans and specifically Aeneas in the founding of Rome. Based on this layering, Annesley could use Virgil telescopically to observe the equally turbulent happenings of his own day against a vast political backdrop. To this

28 'Et quæ tanta fuit Welbeck tibi causa videndi?'

29 British Library, Add. MS 18730, ff. 2r.

30 On the publication of Bate's history, see F. F. Madan, 'A Bibliography of George Bate's Elenchus Motuum Nuperorum in Anglia', The Library, 5-6 (1951), 189-999. For a discussion of the British Civil Wars in Latin verse, see the essays by Victoria Moul: 'Revising the Siege of York: From Royalist to Cromwellian in Payne Fisher's Marston Moor', The Seventeenth Century, 30 (2016), 311-31 and 'Andrew Marvell and Payne Fisher', The Review of English Studies, 68 (2017), 524-48.

31 The locus for this distinction between history and poetry was Aristotle, Poetics, 51a12-13, which was of course popularized in early modern England by Sidney, The Defence of Poesie (London, 1595), D3r. 
end, he not only inserted relevant terms into lines from Virgil, but, more often, he homed in on passages that explicitly communicated the historical reappearance of courageous actors. Upon reaching a description of how religious sectarians precipitated a political climate ripe for dethroning the monarchy, for example, Annesley transcribed the claim from Aeneid Book 1, lines 148-53, that a nobleman usually rises up and leads the people out of harm's way when a state is in confusion. ${ }^{32}$ While he here transforms William into a universal chivalric hero-in the lineage of Aeneas and Caesar-the subtle shifts in his glosses and the usage of poetry as a distancing device suggest that Annesley was cautious not to make value judgements or to valorise the protagonist of De vita as such.

Annesley's quest for nuance often prompted him to dwell not so much on William's triumphs as his manifestation and suppression of passions. On page 48 of De vita, for instance, he recorded the narrator's exclamation from Book 10, lines 507-8 of the Aeneid: 'O you who will go home as a great grief and yet great glory to your father, this day first gave you to war and now it takes the last'. ${ }^{3}$ Whereas his Virgilian quotations regularly encapsulate moments of love and grief, Annesley predictably drew from Seneca to illuminate acts of constancy. Page 110 of De vita relays that William's 'face [was] unequal to his heart' ['animo disparem vultum'] —-meaning that he belied his feelings - upon hearing of his brother's death. At this juncture, Annesley excerpted the claim from De consolatio ad Polybium that successful generals 'conceal their misfortunes by feigning joy, to avoid the soldiers themselves growing faint-hearted because of their leader's broken spirit'. ${ }^{34}$ The reformation of the passions has typically been regarded as an ethical imperative in late Stoic writing, but here Annesley interestingly summons Seneca to applaud William not so much for reforming as concealing his passions. ${ }^{35}$ It is in many ways unsurprising that Annesley continually paired the Aeneid with De vita, since both represent the deeds of an individual at a moment of historical crisis, in marked contrast to an epic such as Homer's Iliad that broadly treats state affairs. But even the timeless characteristics that Annesley found in William were, in the end, less tokens of military might or tactical acumen than finely honed abilities such as dissimulation that were equally applicable in more sociable contexts.

In spite of Annesley's incessant recognition of parallels in the Aeneid and De vita, Virgil's epic was probably not the prototype for The Life of William. While Margaret was excluded from the early modern classrooms that inculcated pupils with Virgilian language and ideals, she nevertheless acquainted herself with classical poetry (mainly through English translation) from a young age. Grounded in this early reading, Cavendish reiterated at intervals throughout her oeuvre that she did 'Reverence Virgil,

'Magno in populo cum sæpe coorta est / Seditio, sævitque animis ignobile vulga. / Jamque faces \& arma volant, furor arma ministrat; / Tum pietate gravem ac meritis si fortè virum quem / Conspexêre; silent, arrectisque auribus adstant: / Ille regit dictis animos, \& pectora mulcet' (De vita, 19).

33 'O dolor, atque decus magnum redditure parenti! / Hæc re prima dies bello dedit, hæc cadem aufert'.

34 'Quod magni Duces semper faciunt, rebus afflictis, ut hilaritatem de industria simulent, \& adversas res adumbrata lætitia abscondant, ne militum animi, si fractam ducis sui mentem viderint, \& ipsi collabantur: id nunc sibi quoque faciendum est. Indue dissimilem animo tuo vultum, si potes, projice omnem ex toto dolorem: si minùs, introrsus abde [et] contine, ne appareat'.

35 See Guido Giglioni, 'Philosophy According to Tacitus: Francis Bacon and the Inquiry into the Limits of Human Self-Delusion', Perspectives on Science, 20 (2012), 159-82 (170-2). 
but yet not so much as I do sweet Ovid'. ${ }^{36}$ Her preference for Ovid might seem strange given that Virgil's standing in Caesar's court sometimes drove Royalists to extol him as the Roman poet par excellence. ${ }^{37}$ That being said, Virgil's Georgics were assimilated to celebrate Cromwell, while Ovidian myths were staples in the court masques that tended to reinforce monarchical authority. ${ }^{38}$ Ovid's banishment also increased his relevance to the exiled Royalists, and George Sandys' 1632 translation of Metamorphoses with its copperplate engravings and extended commentaries-in which Virgil is nonetheless cited persistently_imbued his work with fresh cultural prestige. ${ }^{39}$ Rather than stressing politics, however, Cavendish lauded Ovid's adroit fusion of sundry topics and his proclivity for philosophical rumination. Less approvingly, she censured Virgil for having 'Flattered the Emperour, and the most Noble Families in Rome; and as for his Flattery, he made the Ground of his Poems'. ${ }^{40}$ Although there is a deeply ingrained historiographical assumption that political commitments largely explain why any given mid-seventeenth-century English writer preferred a particular ancient author, Cavendish's partiality towards Roman poets was, on the whole, inversely correlated with the degree to which their writing was ideologically motivated. ${ }^{41}$ She thus deemed Virgil's partisan objectives - which were an outgrowth of his social aspirations-to have infected his otherwise masterful verse.

While Margaret may have criticized Virgil's fawning, we have seen that one of Annesley's fundamental goals in reading De vita was to generate his own chronicle that was not 'obscured by flattering'. As Cavendish must have realized, the very decision to publish a history of her husband's military achievements left her more liable to Virgilian flattery than she wished to admit, since the interspersed praise that ideally stimulated virtuous emulation could not but verge on sycophancy. Seeing as the Aeneid was taught as an archetype of the epideictic-the rhetoric of praise and blame-it is reasonable to infer that Annesley retooled and plotted passages from Virgil onto De vita in part to figure out when Margaret's history actually described exceptionable actions or qualities and when it overstated the accomplishments of William and the Royalist army. ${ }^{42}$

36 Margaret Cavendish, Sociable Letters (London, 1664), 305.

37 See Maggie Kilgour, 'Virgil and Ovid', in Patrick Cheney and Philip Hardie (eds), Oxford History of Classical Reception in English Literature, Volume 2: 1558-1660 (Oxford, 2012), 517-38.

38 See Colin Burrow, 'Virgils, from Dante to Milton', in Charles Martindale (ed.), The Cambridge Companion to Virgil (Cambridge, 1997), 79-90 and Syrithe Pugh, Herrick, Fanshawe and the Politics of Intertextuality: Classical Literature and Seventeenth-Century Royalism (Burlington, VT, 2010), 21-38 and $57-83$.

39 For Cavendish's appreciation of Sandys' translation, see Margaret Cavendish, The World's Olio (London, 1655), 12 and Margaret Cavendish, The Philosophical and Physical Opinions (London, 1655), A2r. On Sandys' Metamorphosis, see Raphael Lyne, Ovid's Changing Worlds: English Metamorphoses, 1567-1632 (Oxford, 2001), 198-258 and Lee Pearcy, The Mediated Muse: English Translations of Ovid, 15601700 (Hamden, CT, 1984), 37-70.

40 Sociable Letters, 304-5. For a robust case against the notion that Virgil and Ovid were read and translated along strictly political lines, see Sheldon Brammall, The English Aeneid: Translations of Virgil, 1555-1646 (Edinburgh, 2015), especially 78-110 and 133-45.

41 The classic text in this mode of historiography is David Norbrook, Writing the English Republic: Poetry, Rhetoric and Politics, 1627-1660 (Cambridge, 1999), especially 23-62.

42 On the Aeneid and epideictic rhetoric, see Craig Kallendorf, In Praise of Aeneas: Virgil and Epideictic Rhetoric in the Early Italian Renaissance (Hanover, 1989) and Brian Vickers, 'Epideictic and Epic in the Renaissance', New Literary History, 14 (1983), 457-537. 


\section{AN INVISIBLE TRANSLATOR}

Irrespective of the degree to which Cavendish herself derived inspiration for The Life of William from Virgil, the shared features of the Aeneid and De vita might have partially surfaced in the process of translation. It is well known that seventeenth-century scholars frequently consulted ancient texts with comparable content as they transposed English works into Latin. To provide a relevant example, the Cavendishes' one-time chaplain and Christ Church fellow, Jasper Mayne (1604-1672), had requested a certain 'young Scholar' at Oxford to render Poems, and Fancies into Latin. ${ }^{43}$ Upon admitting that the 'hardest part of his Task will be how to find out current Roman Words to match' Cavendish's philosophical lexicon, Mayne advised the scholar to 'read Lucretius before he proceed farther; who having softned the most stubborn parts of Natural Philosophy, by making them run smoothly in his tunable Verses, by an easy Imitation will teach him to do the like.. ${ }^{44}$ The translator of The Life of William could have likewise discovered the relevant language in Virgil's poetry, upon which Annesley in turn seized.

Before delving further into Annesley's annotations, it will thus help to identify De vita's translator (and his guiding principles) as far as possible. When the issue has been tackled at all, Charleton is usually presumed to have Latinized The Life of William. ${ }^{45}$ The main reason for this supposition is that he included 'Guilielmi Ducis Novcastrensis vita, Londini, 1678. in Folio' as one of his publications in a postscript to his 1683 Three Anatomic Lectures. ${ }^{46}$ Yet two sections of De vita in manuscript have hitherto gone unnoticed: an unbound draft of the first twenty pages at the University of Nottingham, and part of the third book in the Bodleian. ${ }^{47}$ Curiously, these documents are in different hands, neither of which is Charleton's. Margaret has also scribbled on the back corner of the Nottingham copy that it is 'Concerning my Lords Life in Latne from y'Univ', and Charleton had no affiliation with Oxford or Cambridge. ${ }^{48}$ But it is worth noting that though The Life of William was the only piece from Cavendish's opus that was actually translated, she hoped to have many of her works Latinized and had been in contact with several schoolmen for this purpose. In addition to evidence from her correspondences with Mayne, the Anglican clergyman and principal of St Edmund Hall, Thomas Tully (1620-1676), annotated his copy of Cavendish's 1655 Philosophical and Physical Opinions with the names of scholars who could translate her works, though he unfortunately failed to list a

On Mayne, see Flynn, 'Jasper Mayne', ODNB. For evidence that Mayne was chaplain to the Cavendishes before the Interregnum, see his 1639 letter thanking William Cavendish for choosing him as chaplain: Nottingham University Library, MS Pw 1/181.

44 Collection of Poems, 96-7.

45 On Cavendish and Charleton, see Liam Semler, 'The Magnetic Attraction of Margaret Cavendish and Walter Charleton', in Jo Wallwork and Paul Salzman (eds), Early Modern Englishwomen Testing Ideas (Aldershot, 2011), 55-74 and Line Cottegnies, 'Le "renouveau" de l'épicurisme en Angleterre au milieu du dix-septième siècle de Walter Charleton à Margaret Cavendish - une histoire franco-britannique', Études Épistémè, 14 (2008), 123-73. Also see the speech that Charleton wrote for Cavendish's visit to the Royal Society: 'A short Harangue designed to be made to the President of the Royal Society, at their entertainment of the Duchess of Newcastle with a sight of some select Experiments' that is recorded in Bodleian, MS Smith 13, ff. 21v-23v.

46 Walter Charleton, Three Anatomic Lectures (London, 1683), P3r-4v.

47 See Nottingham University Library, Pw1/609, ff. 1v-20r and Bodleian, MS Rawl D 1208, 97v-116v.

48 Pw1/609, ff. 20r. 
translator for The Life of William. ${ }^{49}$ A close look at the Nottingham manuscript, however, reveals that it differs substantially from the printed text of De vita. In contrast to the relatively unadorned prose of the published work, this manuscript contains high-flown language and intricate syntax: a stylistic discrepancy suggesting that the Nottingham draft was the aborted enterprise of a university fellow.

The third book of De vita in the Bodleian is more promising than the Nottingham manuscript. It only drifts in content from the published text in lacking bracketed clarificatory phrases such as '(ut vulgo vocantur)' ['(they are commonly called)']. ${ }^{50}$ More consistently, the various cases of 'Dominum' in the Bodleian draft are replaced with 'Novocastrium' in the published work. William is thus titled the 'Duke of Newcastle' ['Novocastrium'] in De vita, despite the fact that he was not made a duke until the Restoration. This is a rare deviation from both the Bodleian manuscript and the English original, which vaguely refers to William as a 'Lord' ['Dominum']. But, as the following sections show more fully, this anachronism was intended to bolster William's authority, and thus paradoxically validate the narrative of De vita. Given Margaret's career-long efforts to retroactively update her title (even in already printed books) to reflect her changing status, she probably requested these emendations just before the translation went to press. ${ }^{51}$ The language and style of the third book, in any case, is consonant with the rest of De vita, indicating that the author of this draft composed the published text as a whole. Even though the Bodleian copy is not in Charleton's hand, then, it seems probable that an amanuensis transcribed it as a clean draft for Margaret to review. On the evidence that he was Cavendish's friend, a well-established translator, and that there was nothing obvious to gain in pretending to have produced De vita, this paper continues to credit Charleton with the translation.

The linguistic register of both the Bodleian copy and the published text of De vita also speak to Charleton's role as translator. While he had churned out numerous more or less faithful translations by 1668 , the approach in De vita is closest to Charleton's 1675 translation of Plato's Apology, which is honoured as the earliest English edition of a Platonic dialogue. ${ }^{52}$ Reacting to the famous Latin variants by Marsilio Ficino (1433-1499), Charleton strove to replicate Plato's 'very Expressions, and render them even word for word: it was not that I imagined that way to be either more facil, or more elegant; but because I judged it to be the more faithful, and I had design'd, not a Paraphrase, but a Translation'. ${ }^{53}$ His Plato is, in other words, free of the poetic ecstasy that ensues from Ficino's mystical interpretation, and it has already been noted that the published text of De vita lacks the rhetorical flair of the Nottingham manuscript. It is telling in this regard that Charleton would have translated both Plato's Apology and De vita after 1663, at which point he became one of

51 This is evident, for example, in Poems, and Fancies, Huntington Library, shelfmark 120141, where Cavendish has crossed out the words 'Countess of and replaced them with 'Marchiones'.

52 While the work was in fact published anonymously, Charleton makes his authorship clear both in the postscript to his Three Anatomical Lectures (London, 1683), P3r-4v and his library catalogue: MS Smith 13, ff. $146 \mathrm{v}-7 \mathrm{r}$. 
the earliest fellows elected to the Royal Society. In this setting, plain prose and wordfor-word translations were championed. ${ }^{54}$

From a generic perspective, it is also apposite that Charleton fashioned a faithful translation, for the primary goal of history was to document matters of fact rather than capture a poetic tone or style. Consequently, Margaret would have desired the translation-which might make the text appear another step removed from actual events-to be as seamless as possible. ${ }^{55}$ The fact that the title page only bears Margaret's name further marks the translator's subordination to the original author, as does the lack of a prefatory rationale for the translation. With regard to the annotated copy of De vita, however, Charleton could easily have revealed to Annesley that he had rendered The Life of William into Latin. Not only were they friends, but Charleton in fact resolved to translate Plato's Apology over supper with Annesley and subsequently dedicated the work to him. ${ }^{56}$ Hence Charleton had occasion to reveal his principles of translation to Annesley or even alert him to the fact that Virgil had proven useful in the course of rendering The Life of William into Latin. Indeed, Virgil's prominent place in the classroom through the ages-and particularly during the early modern period-was due in part to the elegance and simplicity of his Latin style. As Charleton was entirely aware, Virgilian language and themes were almost second nature to the educated readership at whom his translation was targeted, and Virgil would have accordingly furnished him with an obvious blueprint for an heroical historical style that complied with Cavendish's aims.

\section{ANCIENT (AUTO)BIOGRAPHY}

Margaret's regular expressions of adulation for Caesar might have also stirred Charleton to draw on Virgil. ${ }^{57}$ Instead of developing her understanding of Caesar circuitously through the Aeneid, however, she consulted Arthur Golding's 1590 The eight books of Caius Julius Ceesar and Clement Edmondes's 1609 Observations upon Caesars Commentaries. Charleton thus reproduced (in lieu of a translation rationale) Cavendish's prefatory acknowledgement from The Life of William that she took 'Caesars Commentaries', with their brevity and perspicuity, as her model. ${ }^{58}$ Upon reading this, Annesley was reminded of Infamia Famiani-a style guide by Kaspar Schoppe (1576-1649), the influential German scholar and controversialist-which likewise claimed that plain language is most appropriate for vocalizing historical truths because it both elevates the grace of the subject and delights the reader. ${ }^{59}$

54 See Felicity Henderson, 'Faithful Interpreters? Translation Theory and Practice at the Early Royal Society', Notes and Records of the Royal Society, 67 (2013), 101-22.

55 For a broad and theoretical discussion of these issues, see Lawrence Venuti, The Translator's Invisibility: A History of Translation (London, 2008). More specifically, see Paul Davis, Translation and the Poet's Life: The Ethics of Translating in English Culture, 1646-1726 (Oxford, 2008).

56 See Plato his Apology of Socrates, and Phaedo, A6v.

57 See, for example, Sociable Letters, 52.

58 De vita, D1v and 1.

59 'Rerum quippe gestarum veritatem profitetur Historicus: quam si plano \& perspicuo orationis genere exposuerit, suo functus jam munere videri debet; tametsi puritati sermonis non æqùe studeat. Hanc si præstet, tanto maiores ei, cùm ab eis quorum Res gestas commemorat, tum à Lectoribus gratiæ debentur' (De vita, 1). On Schoppe, see Jill Kraye, 'Teaching Stoic Moral Philosophy: Kaspar Schoppe's Elementa philosophiae Stoicae moralis (1606)', in Emidio Campi (ed.), Scholarly Knowledge: Textbooks in Early 
Caesar's clarity was thought to stem both from his rhetorical studies with Apollonius Molon (who famously taught Cicero) and his direct experience of the affairs that he described. ${ }^{60}$ Whereas Cavendish upheld Caesar as embodying the humanist ideal of a man equally dexterous in arms and letters, she brought Virgil's historically unfounded and ideologically charged conjectures not only down to flattery but also his temporal distance from the Trojan War. ${ }^{61}$ Since her own writing on the Civil Wars was based on information gleaned either from conversations with William or from the records of his secretary, John Rolleston (1587?-1681), Cavendish tenuously reserved Caesar's first-hand knowledge for herself. Despite her exclusion from political life, she thus exploited the divine union of marriage to elide the difference between the prime actor and his confidant and to associate herself and her husband with the two sides of Caesar. In this sense, The Life of William (and De vita by extension) is neither a biography nor an autobiography in the way that this distinction has come to be understood. ${ }^{62}$

Annesley must have recognized Cavendish's esteem for Caesar, yet he only transcribed one passage from his Commentaries in De vita. This quotation appears when William's troops are defeated at Wakefield, and many of his men are taken prisoner. Finding a suitable passage, Annesley scrawled down Caesar's confession from Chapter 25 of De Bello Alexandrino - which charts his campaigns in Alexandria and Asia-that the collapse of his army was most disquieting because it consisted of friends. ${ }^{63}$ Annesley thus homed in once again on the convergence of the military and social. Although Cavendish would have no doubt appreciated that Annesley found Caesar's annals to resonate with lines from the translation of her history, the 'Few Observations from the Author' ['Appendicula Continens Pauculas Auctoris Observata'] that round off De vita connect the courage, prudence, wit, and good nature of William and Caesar far more positively. ${ }^{64}$ But where Annesley's extract from Caesar may have underwhelmed Cavendish, the eminent scholar and divine, John Pearson (1613-1686), along with the other fellows of Trinity College, Cambridge, touched on all the right chords in their letter of gratitude upon receiving De vita.

Modern Europe (Geneva, 2008), 249-83 and Gábor Almási, 'Rehabilitating Machiavelli: Kaspar Schoppe with and against Rome', History of European Ideas, 42 (2016), 981-1004.

60 See Carol Clark, 'Some Renaissance Caesars', in Miriam Griffin (ed.), Companion to Julius Caesar (Chichester, 2009), 356-70. On Caesar's style and impartiality, see the essays in Kathryn Welch, Anton Powell, and Jonathan Barlow (eds), Julius Caesar as Artful Reporter: The War Commentaries as Political Instruments (Swansea, 1998), especially 111-39 and 139-70.

61 'Inter omnes autem Historias, particularis ista de aliquo insigni Bello, aut illustri Viro, mihi videtur praeferenda. Quales sunt admirabiles illi Caesaris Commentarii' (De vita, D1r). For this as a humanist commonplace, see Emily O’Brien, 'Arms and Letters: Julius Caesar, the Commentaries of Pope Pius II, and the Politicization of Papal Imagery', Renaissance Quarterly, 62 (2009), 1057-97.

62 On the expansive early modern notion of autobiography, see Adam Smyth, Autobiography in Early Modern England (Cambridge, 2010).

63 'At fortuna, quæ plerumque eos, quos plurimis beneficiis oriavit, ad duriorem casum reservat' (De vita, 39).

64 'Observavi multos immerito Caesari comparatos, adulantibus Poetis. Hoc autem de Domino meo fidenter \& vere dicam, Quanquam Caesaris Fortunam non habuit, habuit tamen Caesaris Fortitudinem, Prudentiam, Clementiam, Ingenium. Imo in quibusdam major Caesare' (De vita, 230). On the intellectual cache of Caesar at the time, see Paulina Kewes, 'Julius Caesar in Jacobean England', The Seventeenth Century, 17 (2002), 155-86 and Robert Miola, 'Caesar and the Tyrannicide Debate', Renaissance Quarterly, 38 (1985), 271-89. 
They lauded William as the British Caesar and anticipated that future generations would benefit exceedingly from Margaret's eyewitness account ['oculatâ teste']. ${ }^{65}$ To some degree, this prediction did prove true in the case of Annesley, albeit his annotations as a whole show a reader striving to come to terms with the recent past from as neutral a perspective as possible, rather than simply elevating De vita to the status of Caesar's Commentaries.

Even if Annesley did not go so far as to dub Margaret (or William for that matter) a second Caesar, there is a moment of effusion or even flattery similar to Pearson's in his preface to the 1682 Memorial of the English Affairs. This work was by Cromwell's confidant and member of the First Protectorate Parliament, Bulstrode Whitelocke (1652-1724). Annesley saw it through the press. In this instance, Annesley states that 'Only Julius Caesar writ in this kind with so much care, to discourage any from writing after him'. ${ }^{6}$ Insofar as he variously aligned Caesar with William and Whitelocke, Annesley appears to have revered the Roman statesman more as a reliable historian than as an ideological mouthpiece. Corroborating this point, Annesley's foreword proceeds to compare the manner in which Whitelocke 'conversed with Books' - in contrast to Caesar's experiential knowledge-to the practice of the equally learned but politically inimical 'Portius Cato' (or Cato the Younger). Quoting from Nepos's Vitae excellentium imperatorum, he refers to Cato as 'Reipublicae peritus, \& Jurisconsultus, \& magnus Imperator, \& probabilis Orator, \& cupidissimus litterarum' ['the experienced Republican, jurist, great Emperor, admirable orator, and ambitious man of letters']. ${ }^{67}$ This passage also suggests that Annesley anchored his understanding of Memorials and De vita in similar sources, since his annotated book contains three transcriptions from Nepos.

It was apt that Annesley used Vitae excellentium imperatorum to annotate De vita, since Nepos was the first political biographer, and he notably wrote on the lives of (mainly Greek) generals. In mapping William onto commanders in Nepos's biography, Annesley again emphasized skills and comportment rather than political stripes. On page 129 he compares William with Thrasybulus, the democratic Athenian general, and on page 188 with Miltiades the Elder, who made himself the tyrant of Chersonese under the protection of Athens. This was representative of his wider approach. Annesley was most concerned with viewing both William and the genre of De vita in light of a longue durée. While scholars have previously argued that 'life-writing' or 'biography' emerged as an identifiable sub-genre during the early modern period-and have taken The Life of William to betoken this trendAnnesley clearly conceived of De vita as part of a well-defined and longstanding biographical tradition. ${ }^{68}$

65 'Quos inter Antesignanus CAESAR, Britannorum olim hostis acerrimus, herbam Tibi promptissimè porrigit, priorem lubens agnoscit, \& serò tandem intelligit difficilem fuisse de Insula nostra victoriam, utpote quae Tui similes, \& Tetulerit' (William Cavendish, A Collection of Letters and Poems (London, 1676), 56).

66 See Bulstrode Whitelocke, Memorials of the English affairs, or, An historical account of what passed from the beginning of the reign of King Charles the First, to King Charles the Second his happy restauration (London, 1682), B2v. The best study of Whitelocke remains Ruth Spalding, The Improbable Puritan: A Life of Bulstrode Whitelock, 1605-1675 (London, 1975).

67 Memorials of the English affairs, B1r.

68 On Nepos as a biographer, see Joseph Geiger, Cornelius Nepos and Ancient Political Biography (Wiesbaden, 1985), especially 66-116. On the emergence of life-writing, see Kevin Sharpe and Steven 
Although the subject matter of De vita and Vitae excellentium imperatorum closely coincide, Cavendish's own template for life-writing was rather Plutarch's Parallel Lives, as translated by the English Justice of the Peace and military officer, Thomas North (1535-1604). ${ }^{69}$ But, even then, North's commentaries draw out parallels between the biographical accounts of Nepos and Plutarch. ${ }^{70}$ It is salient here that Cavendish's reading of North's translation of Parallel Lives prompted her to echo Nepos's portrait of Cato-as cited by Annesley in the preface to Memorials - in her 1664 Sociable Letters. While the next section shows that Cavendish and Annesley had different benchmarks for what constituted a trustworthy authority, they were evidently both willing to venerate historical actors regardless of their political allegiances, since Cavendish herself lauded 'Cato Uticensis' for 'his Courage, Honesty, and Wisdom, and for the Love to his Country'. ${ }^{71}$ As the independent yet overlapping concerns of the author and annotator indicate, Annesley's De vita is itself the culmination of a historical process: Cavendish found inspiration for her account in English editions of Roman writers, Charleton leaned on Latin literature when translating The Life of William, and Annesley projected further linguistic and conceptual parallels onto De vita. Each stage of development spawned additional insights and resonances from the Latin past.

\section{CONTROVERSY AND IMPARTIALITY}

In the English Life of William, Margaret explained that she penned a biography rather than a national history partly because the latter tended to renew 'old Quarrels, that would otherwise have been forgotten' ${ }^{72}$ By homing in on the universal nature of individual actions and desires as opposed to overtly political matters, Annesley indirectly approved of this approach. His own stabs at making the manuscripts of both Whitelocke's Memorials and John Milton's 1670 History of Britain-which he also revised for publication-more politically moderate also indicate that he shared Margaret's concern that contemporary political histories could reignite controversies. ${ }^{73}$ On the other side of the ideological spectrum, he was close to the Bodleian librarian, Lady Margaret Professor of Divinity, and Archdeacon of Oxford, Thomas

Zwicker, 'Introducing Lives', in Kevin Sharpe and Steven Zwicker (eds), Writing Lives: Biography and Textuality, Identity and Representation in Early Modern England (Oxford, 2012), 1-26.

69 See James Fitzmaurice, 'Margaret Cavendish's Life of William, Plutarch, and Mixed Genre', in Line Cottegnies and Nancy Weitz (eds), Authorial Conquests: Essays on Genre in the Writing of Margaret Cavendish (Madison, WI, 2003), 80-102 and Lara Dodd, The Literary Invention of Margaret Cavendish (Pittsburgh, PA, 2013), 23-56.

70 On Nepos and Plutarch, see Vicente Ramón Palerm, Plutarco y Nepote: fuentes e interpretación del modelo biográfico plutarqueo (Zaragoza, 1992) and Joseph Geiger, Cornelius Nepos and Ancient Political Biography, 117-20. For references in North, see Plutarch, The Lives of the Noble Grecians and Romanes, trans. Thomas North (London, 1579), 349-50, 576, 773.

71 Sociable Letters, 389. For Cavendish's model, see The Lives of the Noble Grecians and Romanes, 815-48.

72 See Margaret Cavendish, Life of William Cavendishe (London, 1667), C1v.

73 For Annsley's role in the production of Milton's history, see Nicholas von Maltzahn, Milton's 'History of Britain': Republican Historiography in the English Revolution (Oxford, 1991), 15-17. More generally, see David Norbrook, 'The English Revolution and English Historiography', in N. H. Keeble (ed.), The Cambridge Companion to Writing of the English Revolution (Cambridge, 2001), 233-50 and Royce MacGillivray, Restoration Historians and the English Civil War (The Hague, 1974). On Whitelocke, see Blair Worden, 'The “Diary” of Bulstrode Whitelocke', The English Historical Review, 108 (1993), 122-34. 
Barlow (1608-1691), whose writing he deemed to contain 'several things useful to be inserted in the History of that Age', by which he meant the Civil Wars era. Despite eventually publishing and praising the text of the far more whiggish Whitelocke, Annesley proposed that Barlow 'undertake the writing of such a history irrespective of how his politics might inflect his views on recent events. ${ }^{74}$ In the final account, the range of Annesley's publications and friendships only confirms Anthony Wood's remark that it is difficult to isolate 'what sort of men, as to point of Religion, he himself ought in truth to have been ranked' among since Annesley's 'known countenance and encouragement [was] given to persons of very different perswasions. ${ }^{75}$

Annesley took Livy as the chief ancient exemplar for his formation of bonds and acclamation of figures with varied and frequently incommensurable political orientations. As he notes in the preface to Memorials, 'Livy every where made honorable Mention of Scipio, Afranius, and even of Brutus and Cassius, often styling them Excellent Persons; yet was he not the less beloved of Augustus Caesar'? ${ }^{76} \mathrm{He}$ thus attributed peace under the Pax Romana in part to Augustus's tolerant attitude towards those who dared to commend his severest critics and the enemies of his ancestors. It was undeniably clever for a man who swung from opposing to supporting the monarch-and who published a work with a Republican bent while hoping to retain the favour of Charles II-to point out Augustus's leniency with Livy in the introduction to Memorials. Yet, suggesting a more general interest in Livy's ideological latitude, Annesley again cited him on page 30 of De vita, which relays how William ordered his private affairs before going to war. At this instant, Annesley quoted Livy's maxim from $A b$ urbe condita that, in keeping with the natural order of things, one should defend one's own property before taking up arms in the name of one's country. ${ }^{77}$ Such a sentiment fed into the three-tiered notion of Renaissance moral philosophy according to which a citizen should progress, in order of magnitude, from individual ethics, to household oeconomics, before finally engaging politically. ${ }^{78}$ Given his decision to assist in arranging the Restoration principally for the sake of his Irish land, Annesley seems to have lived by Livy's motto.

Perhaps projecting his own lack of firm ideological commitment onto Whitelocke-or even trying to twist Memorials into the impartial history that he never got around to writing-Annesley asserted in the preface that one's political cause is 'more likely to Suffer by the Truth, than the Truth to have any Violence in Favour of a Party. ${ }^{79}$ History, in other words, rarely plays into the hand of ideologues. But, as Annesley's publication of Memorials would have made him painfully aware, it was not always obvious where the truth stopped and a party began. One episode in Memorials,

74 Arthur Annesley, Memoirs of the Right Honourable Arthur Earl of Anglesey (London, 1693), 20-1. Also see Barlow's extended letter to Annesley in The Genuine Remains of that Learned Prelate Dr. Thomas Barlow (London, 1693), 190-201. On Barlow's friendships transcending political and ecclesiastical divides, see Carl Trueman, John Own: Reformed Catholic, Renaissance Man (Aldershot, 2007), 58-9.

75 See Anthony Wood, Athenae Oxonienses, vol. 2 (London, 1692), 598.

76 Memorials of the English affairs, B1r.

77 'Annibalem Italia priùs expelli, quàm bellum in Africam transferatur, Pax, inquit ante in Italia sit, quàm bellum in Africa: \& nobis priùs decedat timor, quàm ultio aliis inferatur' (De vita, 30).

78 See Jill Kraye, 'Moral Philosophy', in Charles Schmitt, Quentin Skinner, Eckhard Kessler, and Jill Kraye (eds), The Cambridge History of Renaissance Philosophy (Cambridge, 1988), 303-86.

79 Memorials of the English affairs, B1r. 
for example, implied that James Butler (1610-1688), the First Duke of Ormond, deserted the King on the battlefield; this contentious point ignited a heated and ongoing dispute between Ormond and Annesley. ${ }^{80}$ There are also moments when Memorials and De vita depart conspicuously. As a case in point, the account in De vita of the immense joy of the civilians and gentry as William took York sits uncomfortably with Whitelocke's claim that 'Newcastle imposed an Oath of Adherence upon the inhabitants of York, to oppose the Scots, but many refused to take it. ${ }^{\prime 1}$ Having spent much time with both De vita and Memorials, Annesley doubtlessly understood that the same events might be framed in a variety of ways. Being fully acquainted with yet distancing himself from the value judgments laden in such accounts, Annesley sought to carve out a picture of recent history that fell squarely on the side of 'truth'.

Within the text of Memorials, the term 'impartial' is notably deployed no less than fifteen times. Annesley's proem thus declares that he need not insinuate 'Indifferency and Impartially' since the author himself 'confesses every-where his Engagements, his Party, when he Proceeded, and when he Retreated, without casting any Mist to Lead you aside'. ${ }^{82}$ Although Annesley's turncoat status made him impartial in the simple sense that he did not wholeheartedly back a single party, he therefore recognized that impartiality could be framed alternatively as candour about prejudices. ${ }^{83}$ Going a step further, Margaret held that a trustworthy (or even impartial) political historian usually backed a single cause, since one who shifted allegiances necessarily lacked conviction and the concomitant moral fortitude. It is apparent from Margaret's admiration of figures such as Cato that her notion of impartiality was based on an individual's qualities rather than their political predilection, but the dedication of De vita to Charles II signals her partisanship from the outset. Even if there is no real equivalent in the much-reduced preamble to De vita, she wrote in the English Life of William that if 'any should say, That those who write Histories of themselves, and their own actions, or of their own Party, or instruct and inform those that write them, are partial to themselves; I answer, That it is very improbable, Worthy Persons, who having done Great, Noble and Heroick Exploits, deserving to be recorded, should be so vain, as to write false Histories. 84 Margaret, for her part, vowed to tell William's story in a manner that befits 'an Impartial Historian' ${ }^{85}$

While it is not immediately obvious why William's heroism and nobility should authenticate Margaret's history, the translation hints at an alternative way to understand impartiality. Because there was no Latin equivalent for 'impartiality', this term

80 See Jane Ohlmeyer and Steven Zwicker, 'John Dryden, The House of Ormond, and Politics of AngloIrish Patronage', The Historical Journal, 49 (2006), 677-706 and Michael Perceval-Maxwell, 'The Anglesey-Ormond-Castlehaven Dispute', in Vincent Carey, Karl Bottingheimer, Ute Lotz-Heumann (eds), Taking Sides? : Colonial and Confessional Mentalités in Early Modern Ireland (Dublin, 2003), 21330.

81 'Miles, vir bello inclytus, eoque tempore Praefectus Eboraci, ingenti Nobilium numero stipatus, Urbis portarum claves, in honoris \& obsequii signum, illi in manus tradidit. Jamque in Urbem triumphanti similis, \& insigni cum laetitia plausuque civium exceptus' (De vita, 25-6). Also see Memorials of the English affairs, 81.

82 Memorials of the English affairs, B1v.

83 For this usage, see Christine Gerrard, 'The Language of Impartiality and Party-Political Discourse in England, 1680-1745', The Emergence of Impartiality, 211-21.

84 Life of William Cavendishe, D1v.

85 Life of William Cavendishe, 1. 
was translated as 'fido' in the opening pages of De vita, which is the first-person singular of 'fidere' and signifies 'faithful' or 'trustworthy' ${ }^{86}$ Richard Serjeantson has convincingly established that a witness's 'fides' - which is the second-person future of 'fidere' and was often translated as 'credit' - set the benchmark for a reliable testimony during the seventeenth century. ${ }^{87}$ The credibility of a witness, in short, had a close affinity with 'impartiality' in some corners. Inasmuch as the virtues of many classical authorities were universally appreciated, they were customarily taken as having the greatest fides and could thus be considered the most impartial. This is another reason why Margaret allied William with Caesar while Annesley, in his turn, relentlessly appealed to the ancients in his annotated De vita and in the preface to Memorials.

Since Annesley's understanding of evidence, testimony, and impartiality deviated from the emphasis in De vita on the authority conferred by nobility and the firm commitment to a cause, it might seem all the more curious that he read this history without voicing any major objections. Yet precisely because he was not ensnared in partisan struggles, Annesley was at liberty to focus on situating De vita in relation to Roman poets and historians such as Virgil and Nepos regardless of their political orientations. By picking and choosing the ancient authors and characters best suited to his purposes as he traced continuities and discontinuities between terminology and themes across time, Annesley hoped to eventually arrive at a frank and balanced perspective on the events of his day.

\section{CONCLUSION: HISTORIOGRAPHY BEYOND POLITICS}

The non-partisan picture of Annesley presented here may once have appeared to sit uneasily with the fact that he invited the poet and occasional polemicist, Andrew Marvell (1621-1678), to use his library to research The Rehearsal Transpros'd (1672-3), that vicious two-part satire on the conservative clerical politics of the Royalist Bishop of Oxford, Samuel Parker (1640-1688). ${ }^{88}$ The Republican Lucy Hutchinson (1620-1681) likewise esteemed Annesley, and famously dedicated her translation of De rerum natura to him. ${ }^{89}$ Yet we have seen that Annesley was equally close to the staunchly traditional Barlow-who also encouraged Cavendish to publish and distribute her works among Oxford colleges - not to mention the ardently Royalist Charleton. ${ }^{90}$ Recasting Annesley's dubious political past, Charleton went so far as to assert in a 1672 letter that 'Providence made use' of Annesley 'to amuse the counsels of the late Usurpers, to their destruction'. ${ }^{91}$ The publication of Memorials may have implicated Annesley in controversies with Ormond as well as the poet and

86 De vita, 1.

87 See Richard Serjeantson, 'Testimony and Proof in Early-Modern England', Studies in History and Philosophy of Science, 30 (1999), 195-236.

88 See Annabel Patterson and Martin Dzelzainis, 'Marvell and the Earl of Anglesey'. For a nuanced discussion of the Marvel/Parker controversy, see Jon Parkin, 'Liberty Transpros'd: Andrew Marvell and Samuel Parker', in Martin Dzelzainis and Warren Chernaik (eds), Marvell and Liberty (Basingstoke, 1999), 269-89.

89 See Lucy Hutchinson, 'Dedication', The Works of Lucy Hutchinson, Vol. 1: The Translation of Lucretius, ed. David Norbrook and Reid Barbour (Oxford, 2012), 5-15.

90 For Barlow's encouragement of Cavendish, see Collection of Letters and Poems, 66 and 68-74.

91 MS Smith 13, ff. 12v. 
playwright John Dryden (1631-1700), but even this seems to have merely been a result of his tempering Whitelocke's history rather than transmuting it into his own ideal (and inevitably unrealized) chronicle.

In his study of Marvell and the circles of the poet-scholar and patron Thomas Stanley (1625-1678), Nicholas McDowell illustrated that political allegiance was only one factor among many that defined seventeenth-century communities. ${ }^{92}$ William Cavendish's own circles were largely Royalist (though Thomas Hobbes, Kenelm Digby, and Ben Jonson can hardly be painted with the same brushstroke), yet even he was most concerned with forging bonds that augmented the intellectual life of his households and his own cavalier image. ${ }^{93}$ According to Edward Hyde (1609-1674), First Earl of Clarendon, William's passions were 'horsemanship, dancing and fencing' along with 'poetry and music'. But, substantiating Cavendish's picture of his loyalty, Clarendon concluded that 'nothing could have tempted him out of those paths of pleasure' other than 'honour, and ambition to serve the king. ${ }^{94}$ Whereas Annesley found solace in poetry and history as he sought to ride (and even subtly guide) the tides of the time, William was unfettered by politics in another sense. Rather than being compelled to cultivate the active political virtues of the Ciceronian tradition, William's unquestioning commitment to the status quowhich was grounded in custom and expectation-granted him the tranquillity necessary to pursue a lavish life and only to fight when called upon.

Despite their divergent approaches to the established order, the very last annotation in De vita highlights how William and Annesley were in some senses kindred spirits in their literary concerns. At the end of De vita, the key figures in William's regiment are listed, and 'Sir William Davenant, the famous poet' is mentioned among them. ${ }^{95}$ Alighting on this reference alone, Annesley projects Virgil's depiction of a certain lyre player named 'Cretheus' in Aeneid, Book 9, lines 775-7, onto 'Davenant, the Muses' friend, whose job was to make songs by stringing notes upon the harp; he forever sang of horses and weapons, of men and battles'. ${ }^{96}$ In accordance with Annesley's annotation from Caesar on the significance of camaraderie in warfare, it is well known that William's decision to select Davenant as Lieutenant General of the Ordinance was based in part on his amity with the one-time poet laureate. This appointment elicited Philip Warwick's judgment (which confirms Hyde's evaluation) that William was 'a romantic spirit, and had the misfortune to have somewhat of the

Nicholas McDowell, Poetry and Allegiance in the English Civil Wars: Marvell and the Cause of Wit (Oxford, 2008).

93 On William's patronage and intellectual circles, see Timothy Raylor, "Newcastle ghosts": Robert Payne, Ben Jonson, and the "Cavendish Circle", in Claude Summers and Ted-Larry Pebworth (eds), Literary Circles and Cultural Communities in Renaissance England (Columbia, MO, 2000), 92-114 and Lisa Sarasohn, 'Thomas Hobbes and the Duke of Newcastle: A Study in the Mutuality of Patronage before the Establishment of the Royal Society', Isis, 90 (1999), 715-37. More generally, see the still useful biography by Geoffrey Trease, Portrait of a Cavalier: William Cavendish, first Duke of Newcastle (London, 1979).

94 Edward Hyde, The History of the Rebellion and the Civil Wars in England, vol. 4 (Oxford, 1839), 484.

95 'D. Guilielmus Davenant, Eques Auratus, \& Poeta insignis' (De vita, 158).

96 'Dav'nant Musarum alumnus, cui carmina semper / Et citharae cordi, numerosque intendere nervis: Semper equos, atque arma virûm, pugnasque canebat' (De vita, 158). 
poet in him'. 97 Yet, given what we have seen, it is highly plausible that William hoped, with Caesar in mind, that Davenant's literary ability might indicate comparable military perspicuity. For his part, Annesley not only foregrounded skills that served William equally in military and courtly settings, but, in keeping with his generally bookish orientation, only thought it necessary to comment on the poet's role in his company.

While the distance between Annesley's reading practices and those of the modern historian or critic might initially appear insurmountable, his copy of De vita finally indicates that a sophisticated and historically sensitive understanding of this text and the epoch in question cannot exclusively or even primarily revolve around sectarian politics. Although some of Annesley's contemporaries certainly did approach ancient works with ideological intent, his annotated book underscores how even a politically engaged actor might turn away from the particularities of party struggles and towards the universalities of Latin literature in efforts to understand and impartially represent those especially tumultuous times.

University of Helsinki 